\title{
Geophysical mapping of the Inland Extension of Deep Ocean Fault Zones, South-Western Nigeria
}

\author{
Gbenga Moses Olayanju ${ }^{1}$ \\ ${ }^{1}$ Applied Geophysics Department, Federal University of Technology, Nigeria \\ Correspondingauthor: Gbenga Moses Olayanju, Applied Geophysics Department, Federal University of \\ Technology, P. M. B. 704, Akure, Nigeria.E-mail : gmolayanju@futa.edu.ng; gmolayanju@gmail.com
}

Received: May 6, 2015

doi:10.5539/esr.v4n2p45
Accepted: May 18, 2015

URL: http://dx.doi.org/10.5539/esr.v4n2p45
Online Published: July 7, 2015

\begin{abstract}
Research activities close to the south western edge of the coastal line has shown inland extension of deep oceanic features identified as regional fault zones. This research work focused on mapping of inland extension of Chain Fault zones into the south-western part of Nigeria using both satellite images and aeromagnetic intensity map over a $55 \mathrm{~km}$ by $55 \mathrm{~km}$ Ifon Basement-Sedimentary area. The area is a transition zone between the south-western basement complex and sedimentary basin of the south-western Nigeria. Interpretations of magnetic field over the area revealed intra-sedimentary features identified as fault zone which form an alignment and inland extension pattern with the offshore Chain fault zone. On the account of the qualitative and quantitative interpretation of the acquired aeromagnetic data, the Landsat-ETM+ multi-spectral bands and Digital Elevation Model (DEM) of the topography of the area, the evidence of inter-sedimentary tectonic events are recorded in the geomorphic characteristics of the study area's terrain in relation to the underlying influence of geology and structural trends revealed by extracted lineaments. From geophysical and geomorphologic interpretations, the observed geomorphic characteristics show three physiographical areas: the northern uplifted block (connection of a series of hills cut by deep-sided valleys), the central SW-NE trending subsided block (or graben) and the southern uplifted block. This geomorphic pattern of a series of flat and highly undulating terrain broken by a series of deep valleys and hills is believed to be related to rifting arising from the influence of the transform fault zones, which subdivide the area into smaller units. The rift valleys in the area are long, deep valleys bounded by parallel faults, or fractures. In addition, the predominant SW/NE, SE/NW and E-W trending linear structures mapped as fracture/faults cut the basement and penetrated the overlying Cretaceous and Tertiary sediments in the study area.
\end{abstract}

Keyword: chain fault zones, transform faults, rifting, inter-sedimentary tectonics, south-western Nigeria embayment

\section{Introduction}

Detailed analyses of the aeromagnetic total intensity field and Landsat-ETM ${ }^{+}$multi-spectral satellite images over Ifon Basement-Sedimentary area of the transition zone of the south-western Nigeria Embayment were carried out in order to study the morphology and structural geologic features underlying the area and possible link with the deep ocean transform fault zones. The study area is characterized by mixed geology characteristics of the basement and sedimentary rocks, which have implications on the structural setting and tectonics of the subsurface geology. Series of studies carried out in this area (e.g., Ako et al., 2004; Onuoha, 1999; Billman, 1992; Ekweozor, 1991; Ako et al., 1980; Olayinka, 1976), have not provided much information about the thickness of the sediments and structural framework of the basin. Evidence about the intra-sedimentary features relationship with the influence of basin margin is yet to be fully established.

In this paper both spectra and Euler Deconvolution were used to analyze total magnetic field data of acquired by the Geological Survey of Nigeria through the airborne survey carried out in 1965 and complied and compiled by Earth Science Limited in 1975. The geophysical investigation was complemented by photo-lineament interpretation using topographic and geologic maps, satellite imagery and Digital Elevation Model of the study area. The study is being extended into adjoining eastern end of the Nigerian section of West African Basement Complex. 


\subsection{Site Description and Geology}

The study area covers a land mass of 3025 square $\mathrm{Km}$ within latitude $6^{\circ} 30^{\prime} \mathrm{N}$ to $7^{\circ} 00^{\prime} \mathrm{N}$ north and longitude $5^{\circ}$ $30^{\prime} \mathrm{E}$ to $6^{\circ} 00^{\prime} \mathrm{E}$ (Figure 1). The area forms a transition zone between the Southwestern Nigeria Basement Complex and its sedimentary Basins.

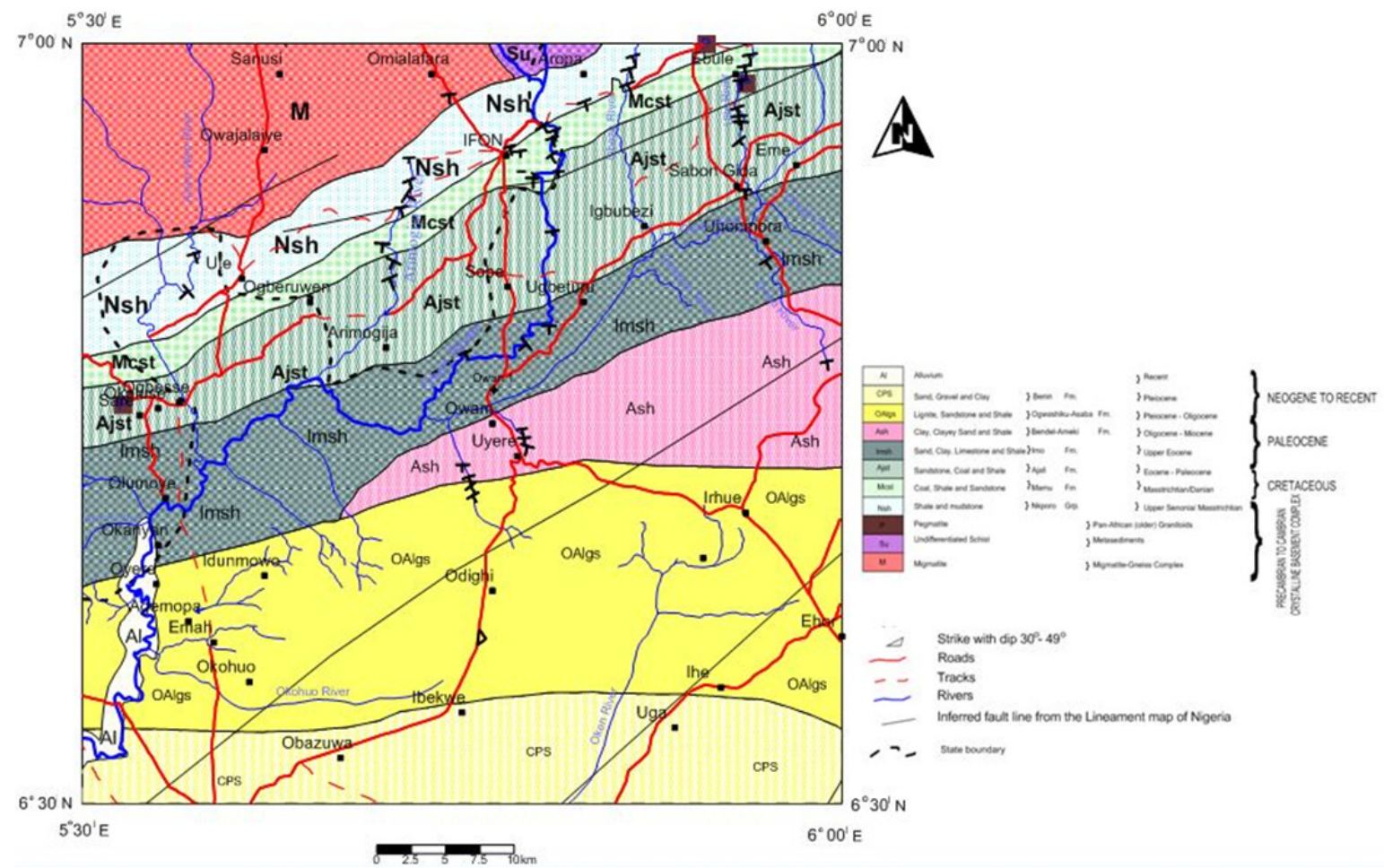

Figure 1. Geological map of the study area (after Olayanju, 2010)

The surface geology reveals rock sequence across the basin is characterized by wide spread of both crystalline Precambrian Basement rocks and sedimentary rocks of Cretaceous to Quaternary age. The northern section is underlain by crystalline rocks typically of the migmatite-gneiss within the eastern edge of the south-western Nigeria basement terrain, while in the south; across the remaining land coverage (over $80 \%$ ), the Precambrian basement is underlain unconformably by the gently dipping sedimentary rocks of the Benin Flank section of Eastern Nigeria Dahomey Embayment (Onuoha, 1999).

Predominant geologic trend is in the NE-SW direction and dips generally in the southwestern direction, which suggests that the rocks in the area were probably subjected to the Pan-African tectonic events (Ekwueme, 2003; Ephrraim et al., 2006).

Physiographically, the area is characterized generally by undulating hills in the north-western part; while southward, the area is predominantly characterized by gentle plains of sediments. From the field observation, it was observed that the rocks in the area have undergone more extensive and continuing geological changes, caused by processes such as faulting, folding, and crustal displacement. The main tectonic events in the study area are faulting and rifting associated with extensional force or pulling apart of the Earth's crust.

The topographic map (Figure 2) reveals that the train is hilly towards the north and fairly a gentle plain towards the south; with the central part characterized by a NE-SW trending valley, which coincides with the Osse river channel, a major river in the area. Surface elevation in the area ranges between $28 \mathrm{ft}(8.5 \mathrm{~m})$ and $1771 \mathrm{ft}(540 \mathrm{~m})$. The relief and drainage patterns are also controlled by both the structure and lithology of the basement rocks.

\section{Method}

The acquired aeromagnetic map (Ifon sheet - 284) of total magnetic intensity of the area on a 1:100,000 scale covering a land expanse of about $55 \mathrm{~km}$ by $55 \mathrm{~km}$ is shown in Figure 3 . The aeromagnetic survey conducted was flown with nominal flight line spacing of $2 \mathrm{~km}$ at nominal altitude of 2,500 $\mathrm{ft}$ (300 meters) above the ground. Digital formats of the Landsat-ETM ${ }^{+} 8$ spectral image bands downloaded from the free Landsat gallery website 
(http://www.Landsat.org/Landsat_galerry). A set of four topographic maps (Ifon NW, NE, SE and SW respectively) on a scale of 1:50,000.

Application programs used for rapid two-dimensional (2D) and three-dimensional (3D) inversions of geosciences data are WingLink 2.5D and Oasis Montaj ${ }^{\mathrm{TM}}$ (Geosoft, 2005) packages. Other application software programs such as Surfer ${ }^{\mathrm{TM}}$ surface mapping package (Version 8.01 from the Golden software Incorporation, Colorado), Statistica ${ }^{\mathrm{TM}}$ and Origin $^{\mathrm{TM}}$ were used in performing end-to-end verification, processing, analysis, integration and geo-statistical analyses of the geopotential datasets.

\subsection{Magnetic Data Analysis}

Both the aeromagnetic and topographic maps were sampled, digitized and transformed to digital formats suitable for automated data processing at an interval of 100 sample points per 3,080 square $\mathrm{km}$ dimension map, resulting into $555 \mathrm{~m}$ cell size along both the $\mathrm{x}$ (east or longitude) and $\mathrm{y}$ (north or latitude) directions. Anti-aliasing and Butterworth filters were applied on the digitized airborne magnetic data to avoid aliasing and remove any noise from the grid data.

In order to enhance the anomaly map and determine more precisely the boundaries of the sources of the airborne magnetic anomaly over the study area, the spectra analysis of the discretized 2D magnetic data grids was conducted through the application of Fast Fourier Transform (FFT) approach involving the Discrete Wavelet Transform (DWT) of the magnetic field at various stages of data processing and interpretations (Oruc and Selim, 2011; Bournas and Baker, 2001; Umego et al., 1995; McCafferty, 1989; Nabighian, 1984; Cordell and McCafferty, 1989).

The processes involved in the spectra analysis of the input aeromagnetic data were carried in three steps:

1. Application of sharpening filters that enhance the shorter wavelength features (shallow geologic structures). These include high-pass filter, downward continuation filters, vertical and horizontal derivative filters.

2. Application of smoothing filters that enhance the longer wavelength features by removing or attenuating the shorter wavelength features. These include low-pass and upward continuation filter.

3. Geophysical transformation involving reduction-to-magnetic equator of the aeromagnetic total field intensity map.

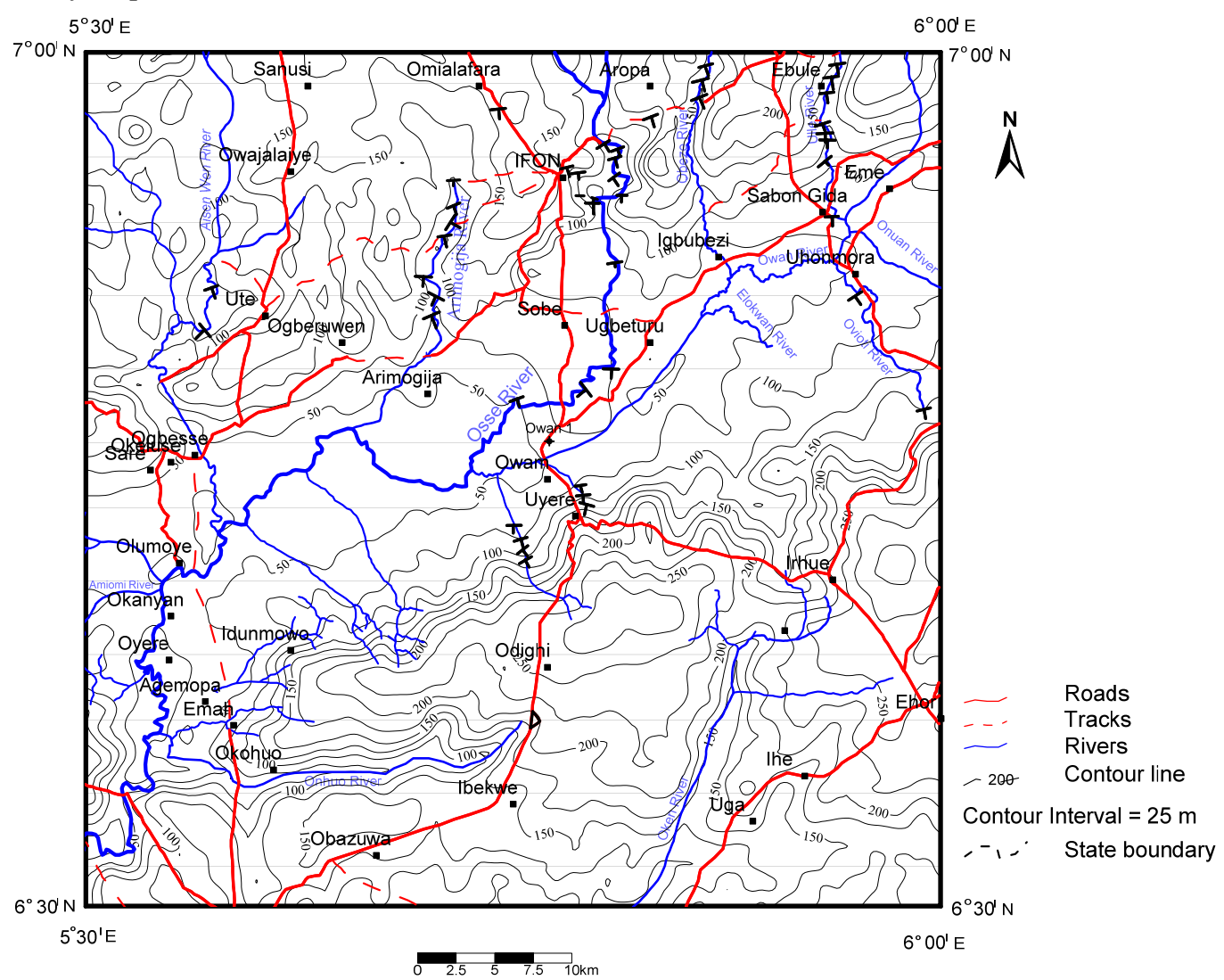

Figure 2. Topographic map of the study area (after Olayanju, 2010) 


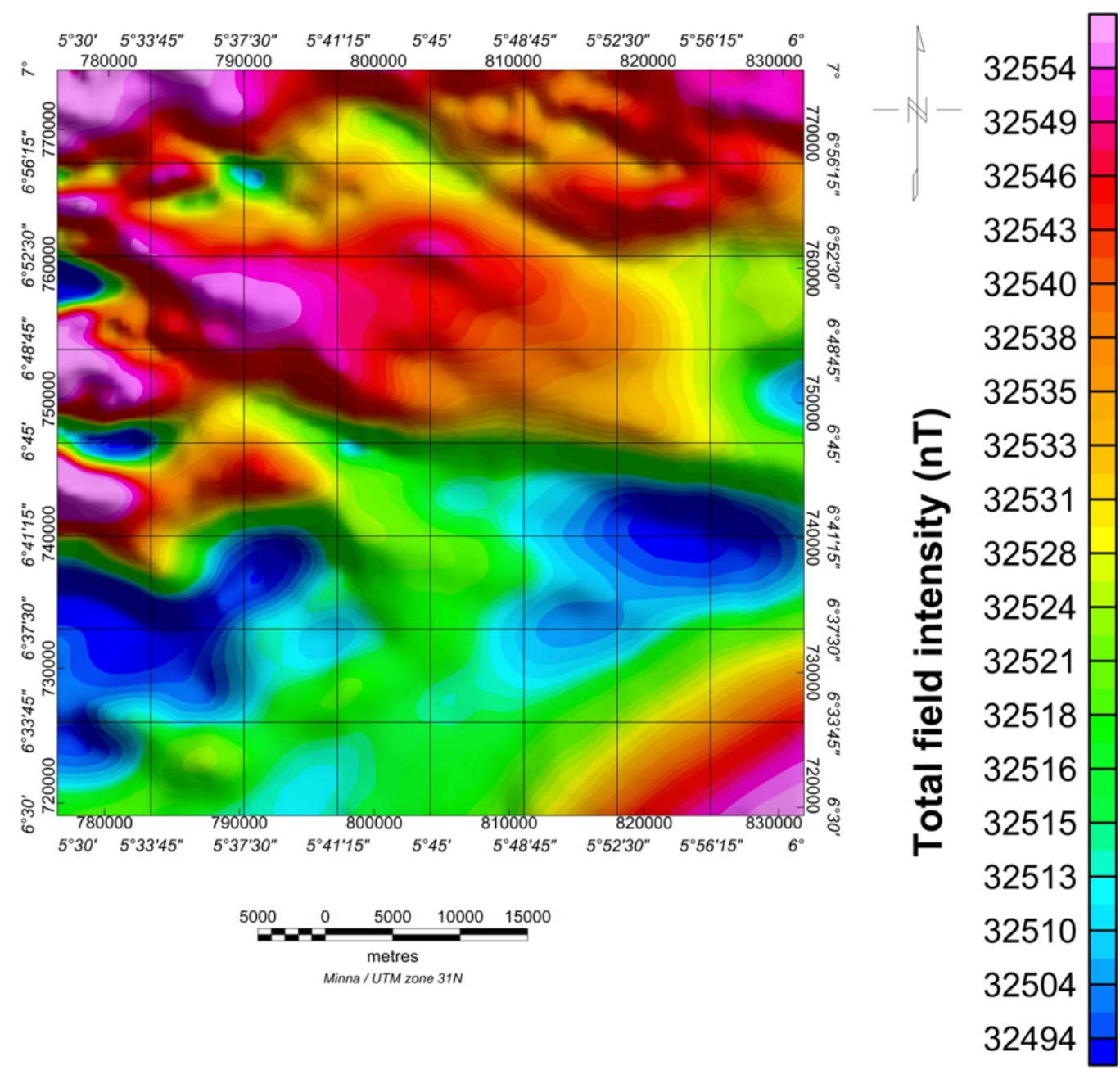

Figure 3. Total Magnetic Intensity Map of the Study Area

\subsection{Lineaments Extraction}

The ILWIS package was used in combining the spectral values of the three individual Landsat-ETM spectral bands, which were imported, geo-referenced to the Universal Traverse Mercator (UTM) Projection and Minna-Nigeria Datum (Zone 31N) grid system, and analyzed onscreen on the integrated Land and Water information system package (ILWIS).

The discretized Topographic image and satellite imageries of the enhanced thematic (ETM) Landsat $\mathrm{TM}^{+7}$ bands data measured in Electromagnetic (EM) bands 4, 5 and 7 were employed to obtain information on tectonic lineaments needed in enhancing interpretation of geophysical data. Peterson (1976) has demonstrated the use of Landsat imagery in interpretation of geologic structures, while according to Rubin (1979) recognition of lineaments, which are traces of fractures or fracture systems on the processed Landsat image, can be based on the tonal effects of the topographic displays (digital elevation model/surface map) of the digitized data points (Ogunmola et al., 2014; Mohammed et al., 2010).

Digital Modelling Surface provided a 3D view of the topographic grid data, which could be attributed to the geomorphology of the study area. From this display, series of linear features, which are related to possible rock boundaries and fractures, were identified from the tonal contrast in the pseudo 3D-visualisation of the topography where gradients are steepest. The geomorphic features include landforms, linear boundaries between different types of terrain, rock or lithologic boundaries and straight stream valleys. Tonal features include straight boundaries between areas of contrasting tone.

Processing of the remotely sensed Landsat-ETM data involved indicative methods of generating thematic maps, which involved (a) RGB colour separation and generation of colour composite maps, (b) Vector-Segment, and (c) Statistical analyses. Figure 4 shows the processed composite thematic image from the combination of Landsat $\mathrm{TM}^{+7}$ spectral bands 4,5 and 7 using the ILWIS package. 
The use of these bands, which are close to ultra-violet ranges, enables easy recognition and interpretation of tectonic lineaments (faults) and to retrieve information about the drainage patterns, roads and Towns. Identification of lineaments therefore revolves around the identification of the geomorphic features (caused by relief) and contrast caused by tonal differences (Nama, 2004; Mah et al., 195; Sabins, 1978).

\subsection{Geophysical Data Inversion}

The inverse method employed for the interpretation of the airborne magnetic data involved the 2D Spectral and 3D Euler techniques with the aid of the USSG (Phillips, 1997) and Oasis Montaj ${ }^{\mathrm{TM}}$ geo-potential inversion programmes in order to determine the geometry (shape and location) and depth to anomaly sources.

The spectral inversion method involved direct ways to depth - to - bedrock computation from the total magnetic intensity data sets based on the radially-averaged power spectrum (RAPS) analysis of the potential fields' data (Githiri et al., 2012). The two dimensional expression for the power spectrum of the total magnetic intensity anomaly over prismatic body was expressed as a function of the spatial frequencies $\mathrm{u}$ and $\mathrm{v}$ (Bhattarcharyya, 1966) for the $x-y$ data grid. The reduced form of the power spectrum $\mathrm{R}_{\mathrm{n}}$ of the geopotential field (Blakely,

1996) is of the form:
$R_{n}=(n+1) \sum_{m=0}^{n}\left[\left(g_{n}^{m^{2}}\right)+\left(h_{n}^{m^{2}}\right)\right]^{\frac{1}{2}}$

where:

$g_{n}^{m^{2}}$ and $h_{n}^{m^{2}}$ are harmonic coefficients of the geomagnetic field.

In general the spectrum of the total magnetic intensity data usually comprise of three portions: the deep source, the shallow anomaly and noise. More accurate depths are obtained by progressively stripping off effects of the shallowest ensembles (or equivalent layers), and by correcting the power spectrum for source body width (Tanaka et al., 1999; Spector and Grant, 1970) or for fractal magnetization models (Pilkington et al., 1994).

The spectrum for a prismatic body is expressed by Fourier expression:

$$
\bar{f}(u, v)=e^{-h_{t} r}-e^{-h_{b} r}
$$

where:

$\mathrm{h}_{\mathrm{t}}=$ depth to the top surface;

$\mathrm{h}_{\mathrm{b}}=$ depth to the bottom surface.

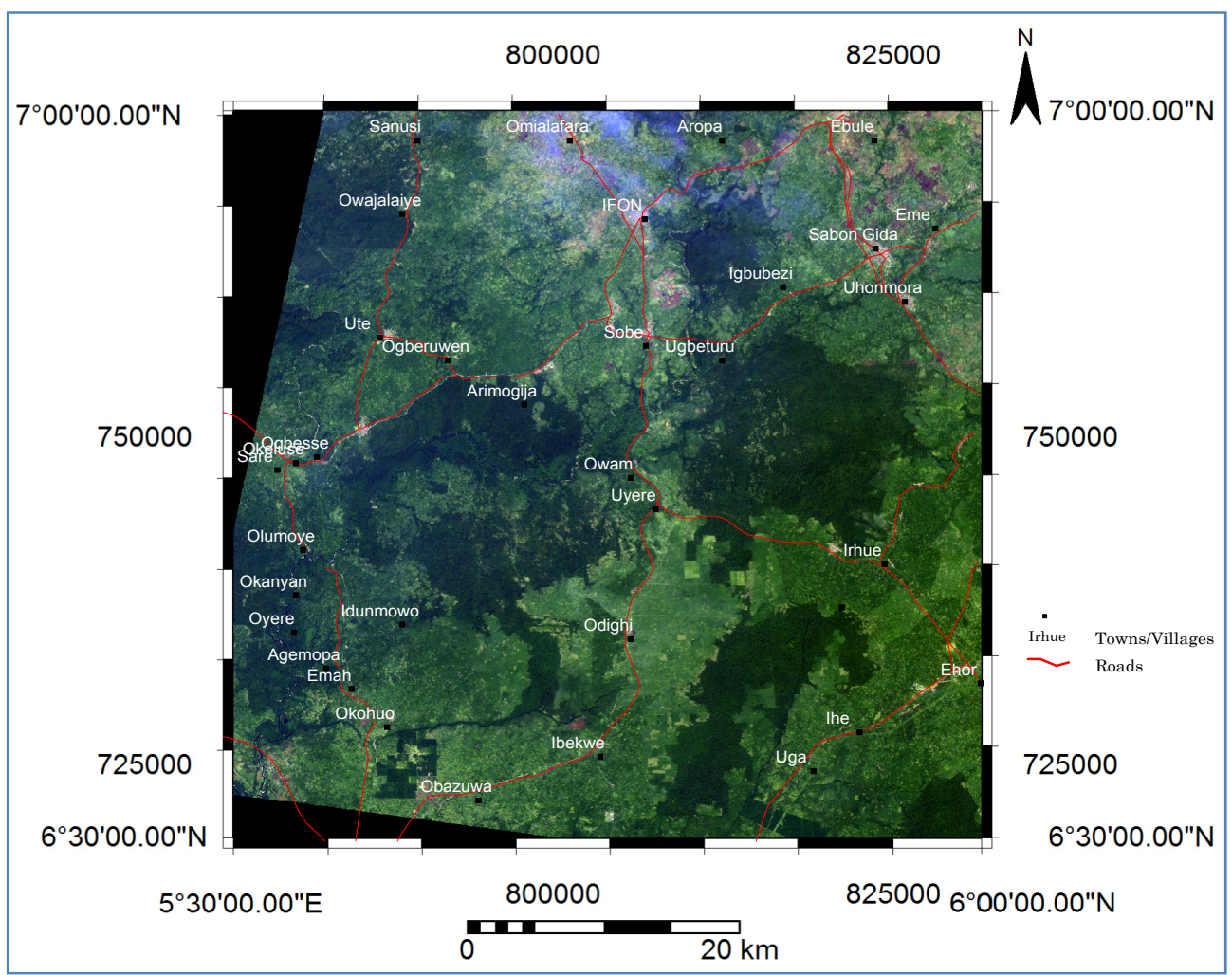

Figure 4. Composite Thematic Landsat Image of the Study Area 
According to Bhattarcharyya (1966) and Cornard et al., (1983) the spectrum for a bottomless prismatic body peaks at the zero wave number and can be expressed as:

$$
\bar{f}(u, v)=e^{-h_{t} r}
$$

The peak wave number $\left(\omega^{\prime}\right)$ is given by the expression:

$$
\omega^{\prime}=\frac{\ln \left(h_{b} / h_{t}\right)}{h_{b}-h_{t}}
$$

The 2D Spectral analysis in the Fourier domain of the total magnetic intensity data was performed using a robust MAGMAP 2D-FFT program in the Oasis Montaj ${ }^{\mathrm{TM}}$ geophysical interpretation software. The MAGMAP 2D-FFT program of the geophysical interpretation platform was used to enhance, extract derivatives, compute analytical signals and estimate depth-to-source of anomalies of the gridded airborne magnetic data based on the power spectra analyses of the geophysical data. Application of spectral method is effective in solving geologic structural problems and map depth-to-bedrock (or magnetic basement) (Hassan and Peirce, 2007; Onyedim et al., 2006b; Onyedim et al., 2006a; Tanaka, et al., 1999; Nur et al., 1994;).

The second approach involved three-dimensional (3D) Euler Deconvolution method (Oruc and Selim, 2011; Dewangan et al., 2007; Reid et al., 1990; Marson and Klingele, 1993; Thompson, 1982) carried out to determine the shape and depth to magnetic anomaly sources, using both the 'Standard Euler' and 'Located Euler' Deconvolution approaches in order to arrive at the best results. Locations of peak-like structures were based on the Blakely (1996) method; using the highest sensitivity level to find all ridge peaks in the analytic signal map of the aeromagnetic data as described by Roest et al. (1992). Homogeneity equation derived by Thompson (1982) forms the basis of 3D Euler deconvolution and relates the geopotential field (magnetic or gravity) and its gradient components to the location of the source. Euler expression for a homogenous 3 dimensional geopotential field of degree $n$ has the form:

$$
f(t x, t y, t z)=t^{n} f(x, y, z)
$$

Potential fields which also satisfy the equation below known as Euler equation are referred to as harmonic functions:

$$
x \frac{\partial f}{\partial x}+y \frac{\partial f}{\partial y}+z \frac{\partial f}{\partial z}=n f
$$

The usual Euler's equation is re-arranged in the form:

$$
\left(x-x_{0}\right) \frac{\partial T}{\partial x}+\left(y-y_{0}\right) \frac{\partial T}{\partial y}+\left(z-z_{0}\right) \frac{\partial T}{\partial z}=N(B-T)
$$

where $\left(\mathrm{x}_{0}, \mathrm{y}_{0}, \mathrm{z}_{0}\right)$ is the position of a source whose total magnetic field $\mathrm{T}$ is detected at $(\mathrm{x}, \mathrm{y}, \mathrm{z})$. $\mathrm{B}$ is the regional value of the total field and $\mathrm{N}$ is the structural index equivalent to $-\mathrm{n}$ in the Euler's equation.

Thompson (1982) has shown that magnetic models conform to Euler's equation, with the degree of homogeneity $\mathrm{N}$ interpreted as a structural index describing the rate of change of the field with distance. The structural index usually assumes values that range between 0 and 3 (Table 1).

According to Reid et al. (1990) the structural index becomes 0.5 for a contact model, provided that the right side of equation (3) represents offset A which incorporates amplitude, strike and dip factors, i.e.,

$$
\left(x-x_{0}\right) \frac{\partial T}{\partial x}+\left(y-y_{0}\right) \frac{\partial T}{\partial y}+\left(z-z_{0}\right) \frac{\partial T}{\partial z}=A
$$

The results of the Euler Deconvolution were later used to produce maps that show the locations and depth of geologic sources of magnetic anomalies observed in the two dimensional (2D) grid (i.e., map/image).

\section{Results}

\subsection{Geomorphologic and Lineament}

Figure 5 shows the geomorphologic pattern identified from the lineament identification analysis using the DEM map. The extracted lineament information from the thematic map derived from the processed Landsat-ETM+ multi-spectral bands images is also presented as Lineament map shown in Figure 6. These maps show series of linear features in form of ridges and valleys in the study area. Intrinsic characteristic parameters of the structural lineaments from the processed DEM and thematic map of the processed Landsat-ETM+ multi-spectral bands images were interpreted in terms of Lineaments' Frequency, orientations and length as presented in Figure 7 and Table 2 . 
Table 1. Structural indices for simple geologic models and their infinite dimensions

\begin{tabular}{lll}
\hline Structural index & Geologic model & Number of infinite dimensions \\
\hline 0 (or 0.5) & Contact & $3(\mathrm{x}, \mathrm{y}, \mathrm{z})$ \\
1 & Sill & $2(\mathrm{x}$ and $\mathrm{y})$ \\
1 & Dyke & $2(\mathrm{z}$ and $\mathrm{x}-\mathrm{y})$ \\
2 & Horizontal cylinder & $1(\mathrm{x}-\mathrm{y})$ \\
2 & Pipe & $1(\mathrm{z})$ \\
3 & Sphere & 0 \\
\hline
\end{tabular}

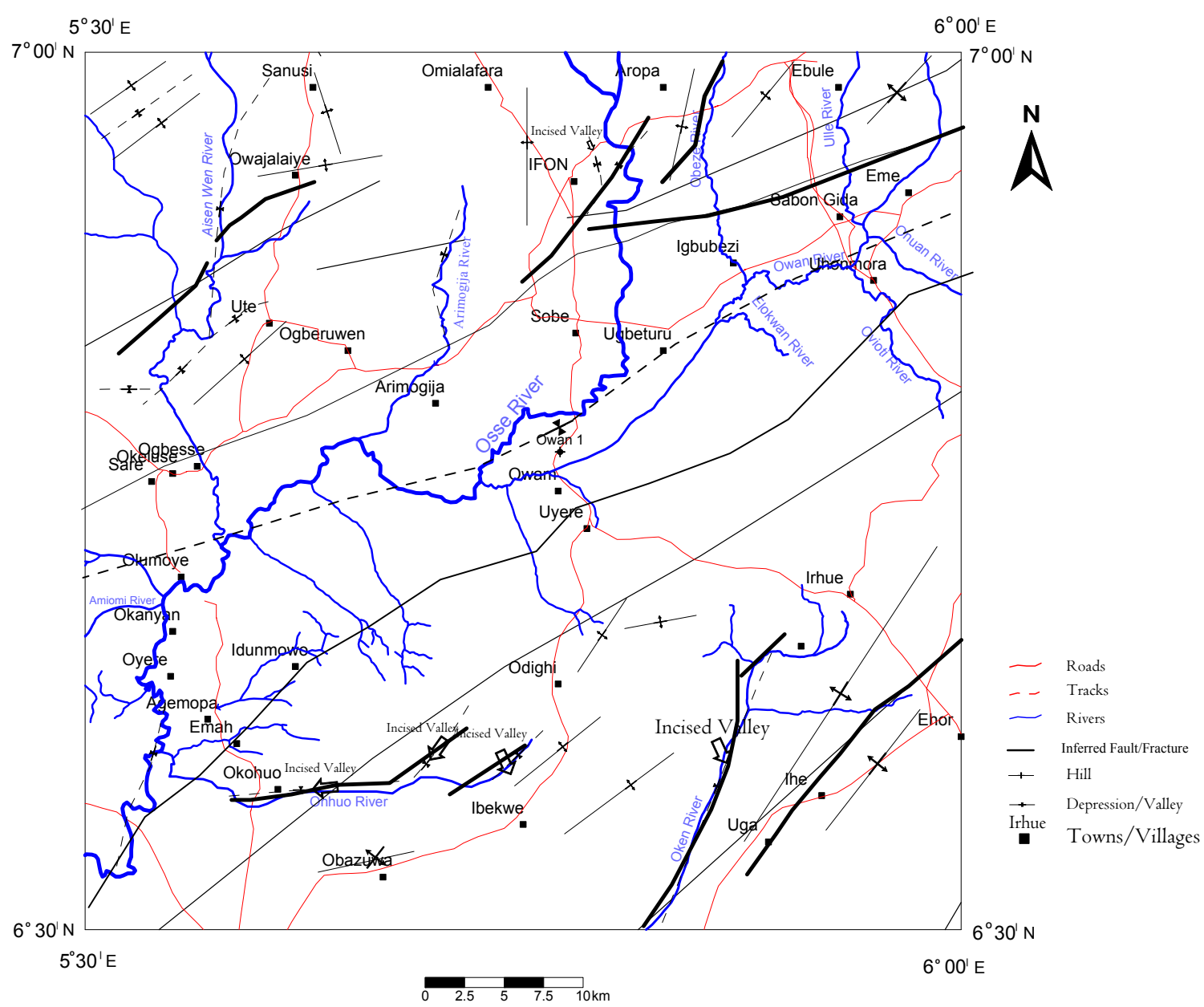

Figure 5. Structural indicative results from the Digital Elevation Model (DEM) of the study area 


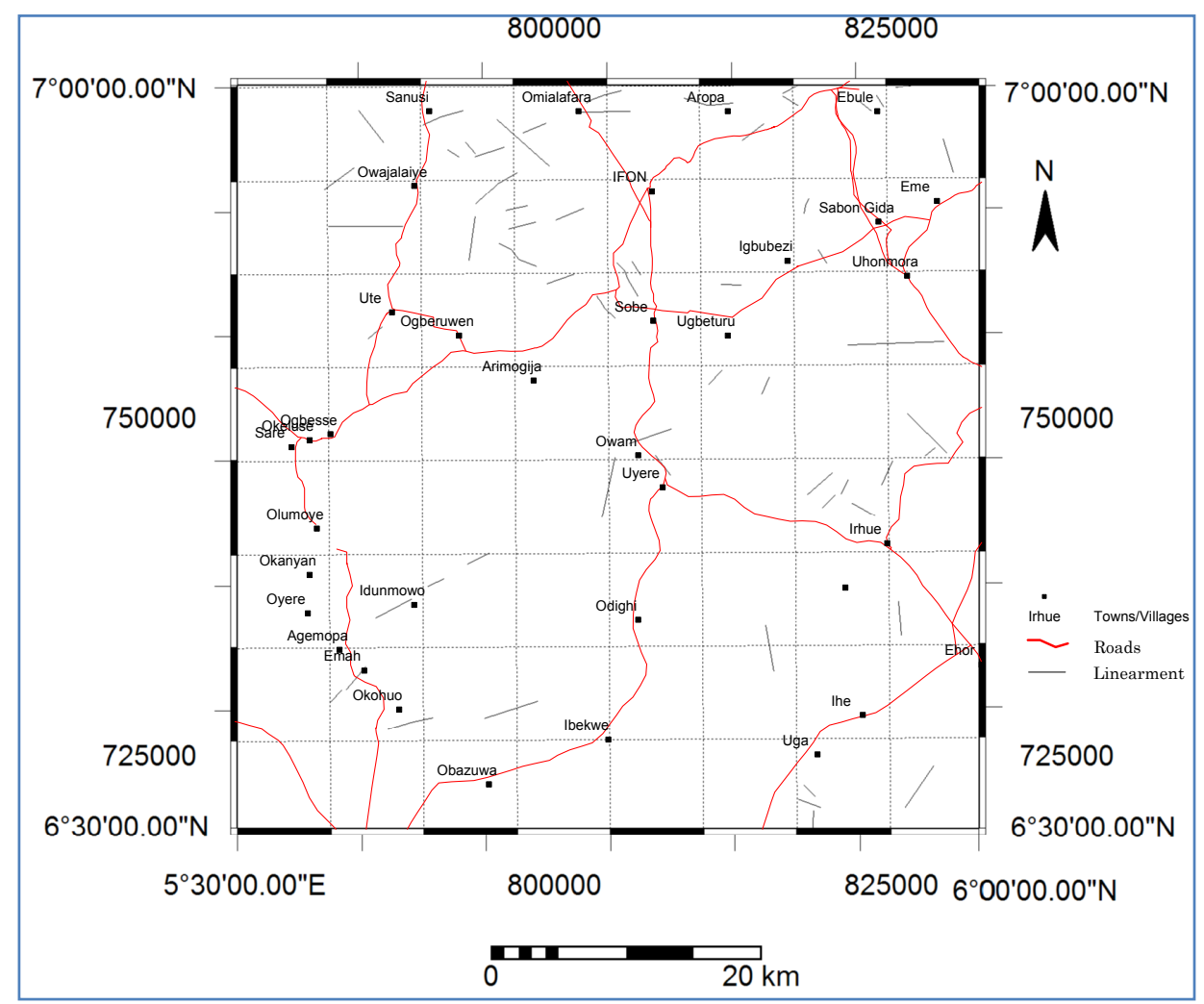

Figure 6. Extracted lineaments map from the Landsat image of the study area
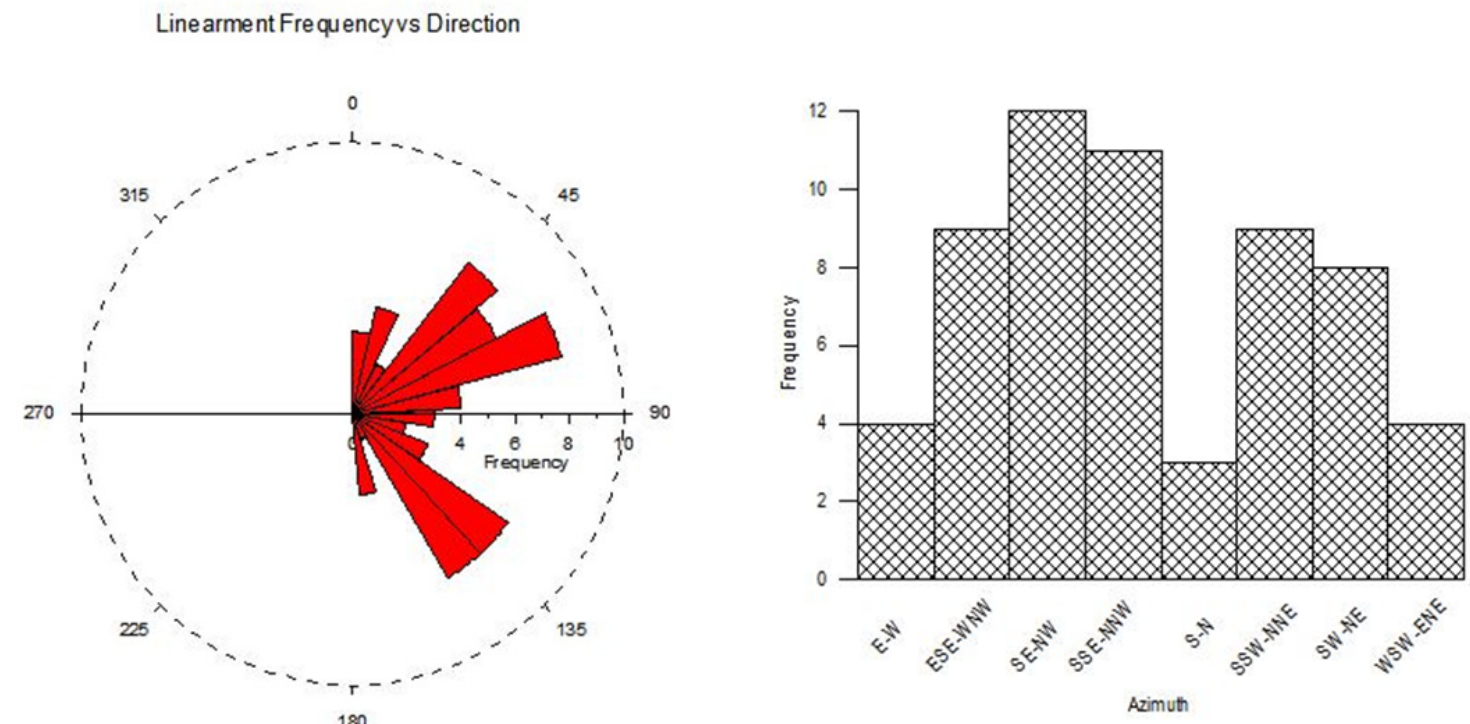

Figure 7. Azimuthal Distribution of Landsat-ETM Lineaments over the Study Area, [A] Rose Diagram and [B] Frequency Distribution Chart 
Table 2. Statistical Estimate Fracture Orientation and Length from Landsat Image Analysis

\begin{tabular}{|c|c|c|c|c|c|c|c|c|c|c|c|}
\hline Dir. & Length & Dir. & Length & Dir. & Length & Dir. & Length & Dir. & Length & Dir. & Length \\
\hline 0 & & 30 & 580.9 & 60 & & 90 & 9445.7 & 120 & 1043.7 & 150 & 2691.1 \\
\hline 1 & & 31 & & 61 & 1597.5 & 91 & & 121 & 1388.5 & 151 & \\
\hline 2 & & 32 & & 62 & 1254.5 & 92 & 1545.5 & 122 & & 152 & \\
\hline 3 & & 33 & & 63 & 4842.6 & 93 & & 123 & & 153 & \\
\hline 4 & 1830.4 & 34 & & 64 & 1308.5 & 94 & & 124 & & 154 & \\
\hline 5 & 610.8 & 35 & 3758.6 & 65 & & 95 & & 125 & & 155 & \\
\hline 6 & & 36 & & 66 & & 96 & & 126 & & 156 & \\
\hline 7 & & 37 & & 67 & 7008.4 & 97 & & 127 & 1055.5 & 157 & \\
\hline 8 & 3311.5 & 38 & & 68 & 1132.0 & 98 & & 128 & 1324.1 & 158 & \\
\hline 9 & & 39 & & 69 & & 99 & & 129 & & 159 & 653.5 \\
\hline 10 & & 40 & 2212.6 & 70 & 3347.8 & 100 & & 130 & & 160 & \\
\hline 11 & & 41 & & 71 & 2144.7 & 101 & & 131 & 5183.1 & 161 & \\
\hline 12 & & 42 & & 72 & 6484.5 & 102 & & 132 & 1067.9 & 162 & \\
\hline 13 & 4484.4 & 43 & 1238.0 & 73 & & 103 & & 133 & & 163 & 2613.8 \\
\hline 14 & & 44 & 1440.7 & 74 & 3659.9 & 104 & & 134 & 5356.1 & 164 & \\
\hline 15 & & 45 & 37.4 & 75 & & 105 & & 135 & 74.8 & 165 & \\
\hline 16 & & 46 & 2378.9 & 76 & & 106 & 1811.4 & 136 & 767.3 & 166 & \\
\hline 17 & & 47 & 1366.9 & 77 & 3435.2 & 107 & & 137 & & 167 & \\
\hline 18 & & 48 & & 78 & & 108 & & 138 & 1133.1 & 168 & \\
\hline 19 & & 49 & 2514.0 & 79 & 3232.8 & 109 & & 139 & & 169 & \\
\hline 20 & & 50 & & 80 & & 110 & & 140 & 863.9 & 170 & 3467.0 \\
\hline 21 & & 51 & 1365.0 & 81 & & 111 & 3208.5 & 141 & & 171 & \\
\hline 22 & & 52 & 2898.4 & 82 & & 112 & & 142 & 4733.0 & 172 & \\
\hline 23 & 1375.8 & 53 & & 83 & & 113 & & 143 & & 173 & \\
\hline 24 & 1942.3 & 54 & & 84 & 1085.6 & 114 & & 144 & & 174 & \\
\hline 25 & 1136.5 & 55 & 2752.8 & 85 & 1950.7 & 115 & & 145 & 1196.5 & 175 & 2601.5 \\
\hline 26 & & 56 & & 86 & & 116 & & 146 & & 176 & \\
\hline 27 & & 57 & & 87 & & 117 & & 147 & & 177 & \\
\hline 28 & & 58 & 304.7 & 88 & 7174.2 & 118 & 1985.7 & 148 & 1189.2 & 178 & \\
\hline \multirow[t]{6}{*}{29} & & 59 & & 89 & & 119 & & 149 & 1014.5 & 179 & \\
\hline & & & & & & & & & Min & 0 & 37.4 \\
\hline & & & & & & & & & Max & 179 & 9445.7 \\
\hline & & & & & & & & & Avg & 90 & 2410.24 \\
\hline & & & & & & & & & StD & 52 & 1893.307 \\
\hline & & & & & & & & & Sum & 16110 & 144614.4 \\
\hline
\end{tabular}

\subsection{Geophysical Data Inversion}

\section{D Spectral Inversion}

The spectral frequency analysis conducted on the aeromagnetic data was employed to separate the magnetic anomalies for the reduced to magnetic equator magnetic map into the deep-seated (regional) magnetic component and the near-surface (residual) magnetic component maps using the spectral frequency analysis and filtering technique.

Based on the results of the spectral analysis conducted, depth estimate to magnetic anomalies sources were computed in order to effectively map the bedrock relief within the 64 sub-grids of the halve degree by halve degree aeromagnetic map of the study area.

The two dimensional (2D)-power spectrum of the airborne total-intensity magnetic data over the study area is shown in Figure 8, while Figure 9 shows the decomposition of the original aeromagnetic total-intensity spectrum into the Regional and Residual components through application of the spectral filters on the discretized aeromagnetic data

\section{D Euler Solutions}

The analytic signal computed from the three orthogonal derivatives of the aeromagnetic data energy spectrum is 
shown in Figure 10, while results of the three dimensional standard and located Euler deconvolution are presented as two dimensional (2D) views. Typical Euler solutions for structural indexes of $0,0.5$ and 1 are shown in Figures 11 to 13. These show series of SE-NW, E-W and S-N trending anomaly peaks orientation, which conform to the inferred general geologic trend in the extracted lineaments map from the Landsat imagery. Statistical summary of the results of the Euler inversion of the aeromagnetic data based on respective geologic models is presented in Tables $3 \& 4$.

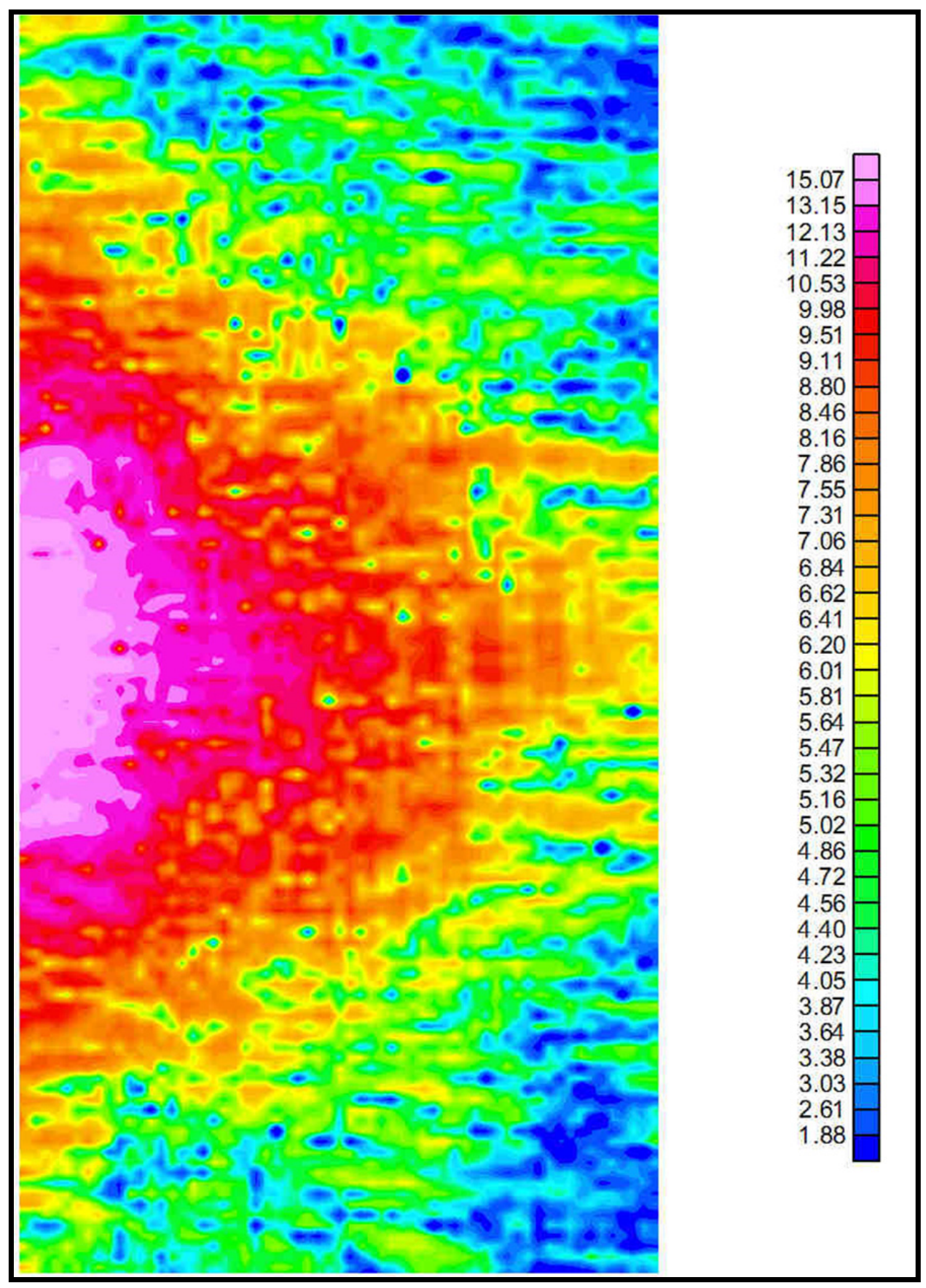

Figure 8. 2D Power Spectrum of the Aeromagnetic Data 

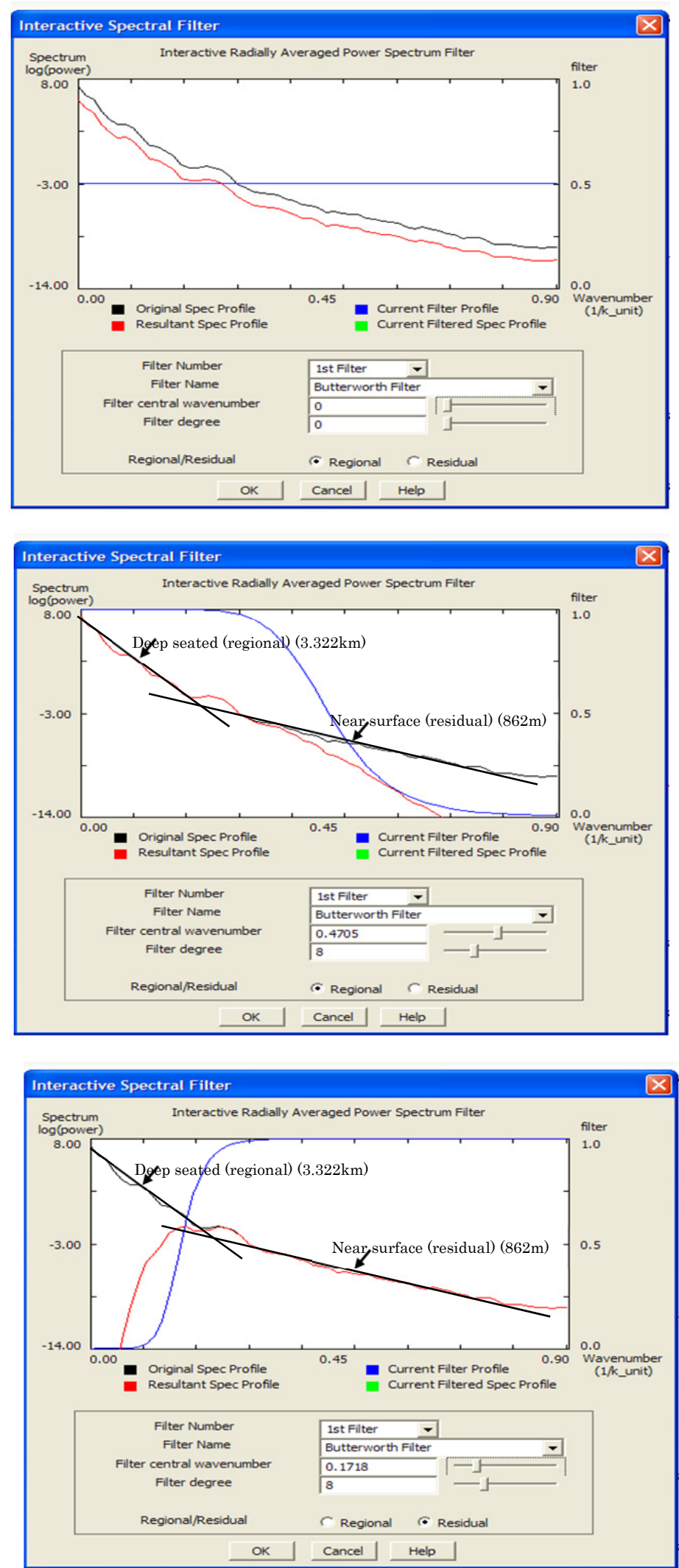

Figure 9. Typical interactive Spectral Filter Response for; [A] Unfiltered Total Magnetic Field, [B] Deep-Seated (Regional), and [C] Near Surface (Residual) Airborne Magnetic Effects in the Study Area 


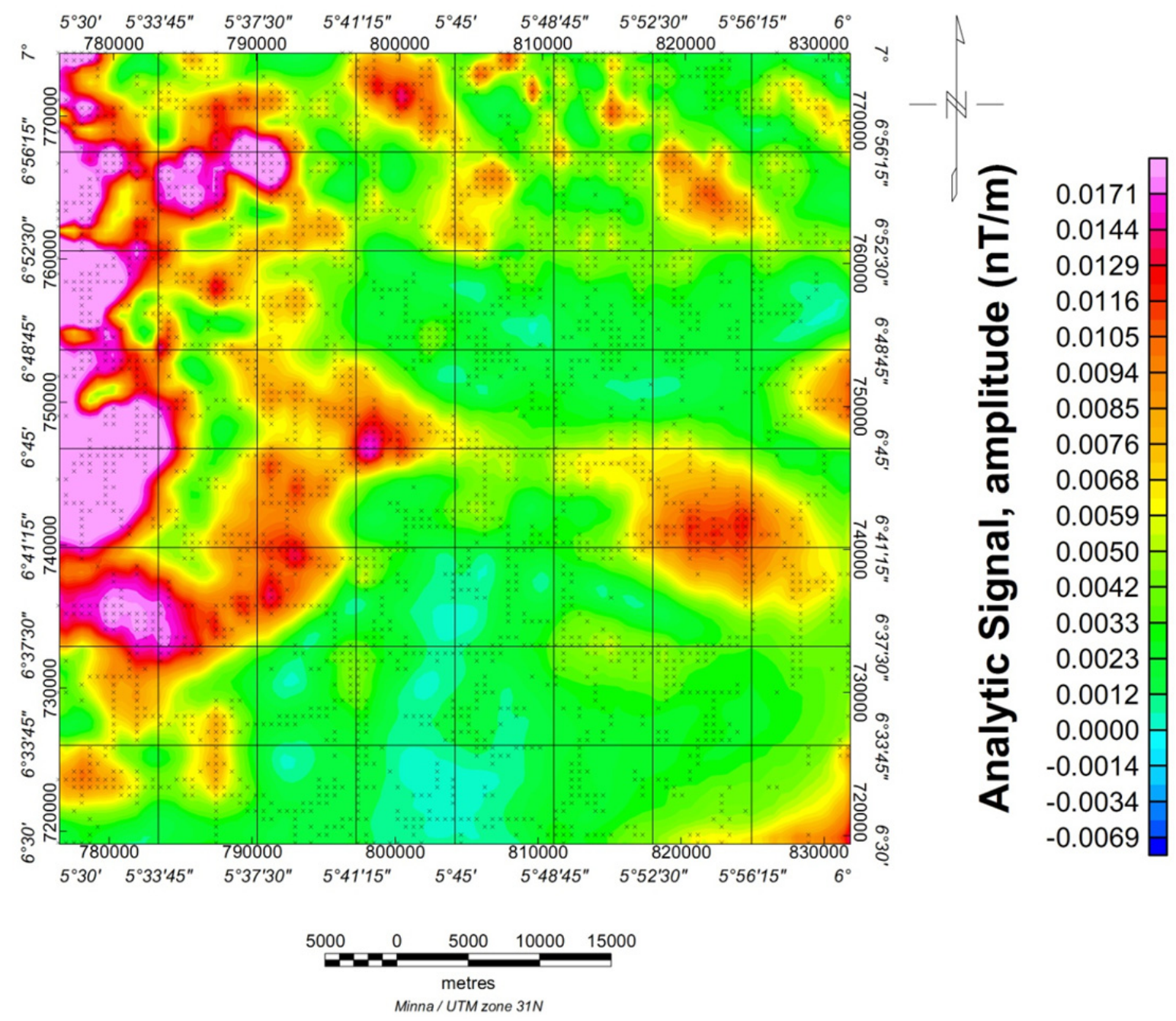

\section{Analytic signal image of the aeromagnetic data}

Computed from the Aeromagnetic data

Figure 10. Analytic Signal of the Aeromagnetic Data 


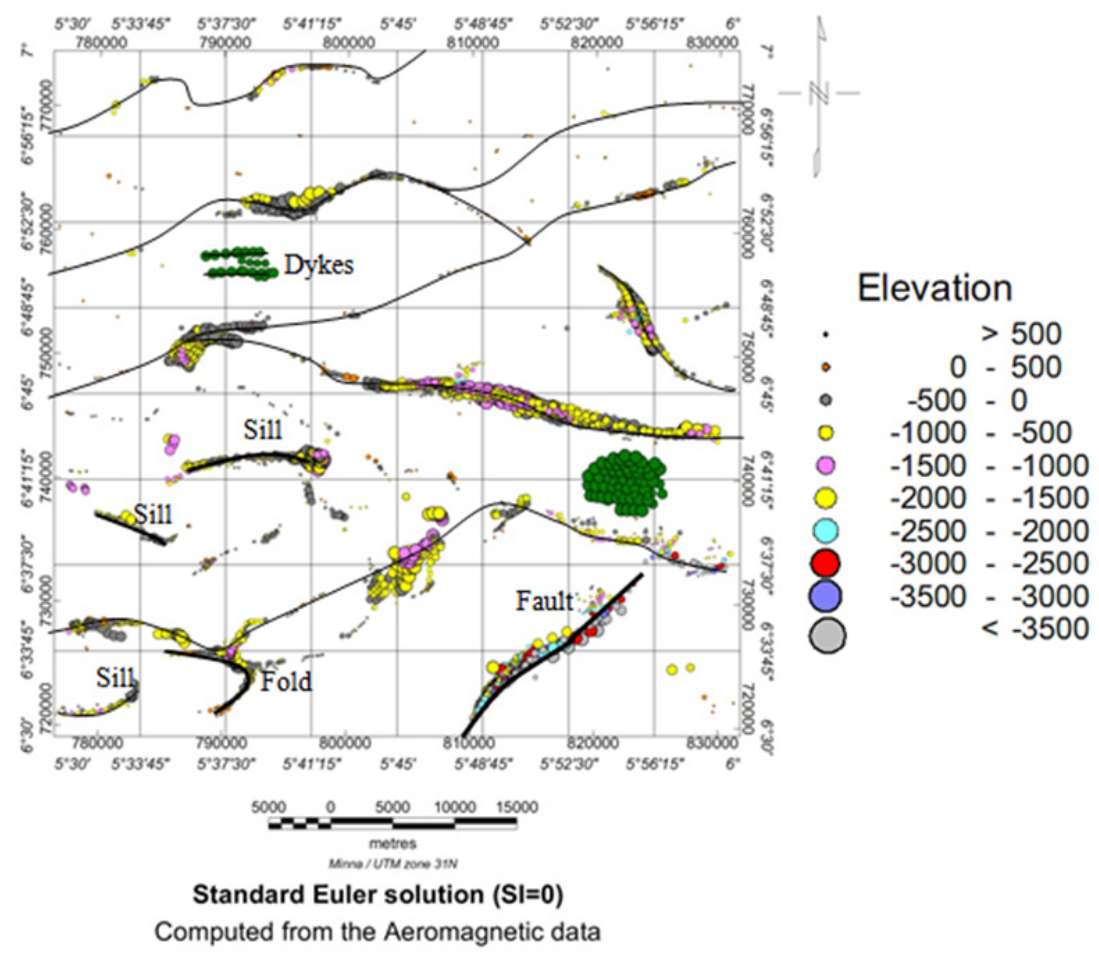

Figure 11. Results of Euler 3D Euler inversion of the aeromagnetic data for the Contact model (structural index $=0)$

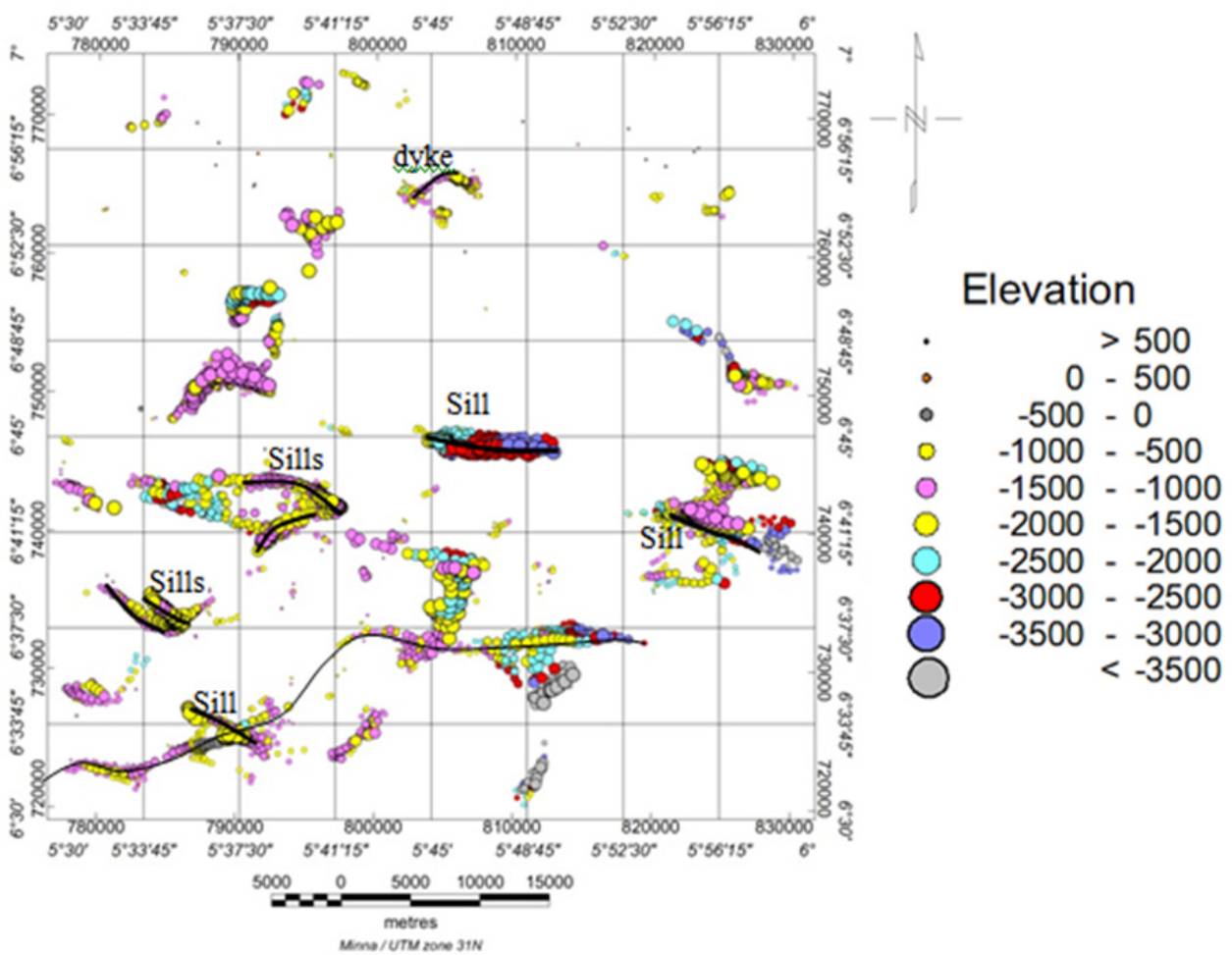

Standard Euler solution ( $\mathrm{SI}=\mathbf{0 . 5}$ )

Computed from the Aeromagnetic data

Figure 12. Results of Euler 3D Euler inversion of the aeromagnetic data for the Contact/Fault model (structural index $=0.5$ ) 


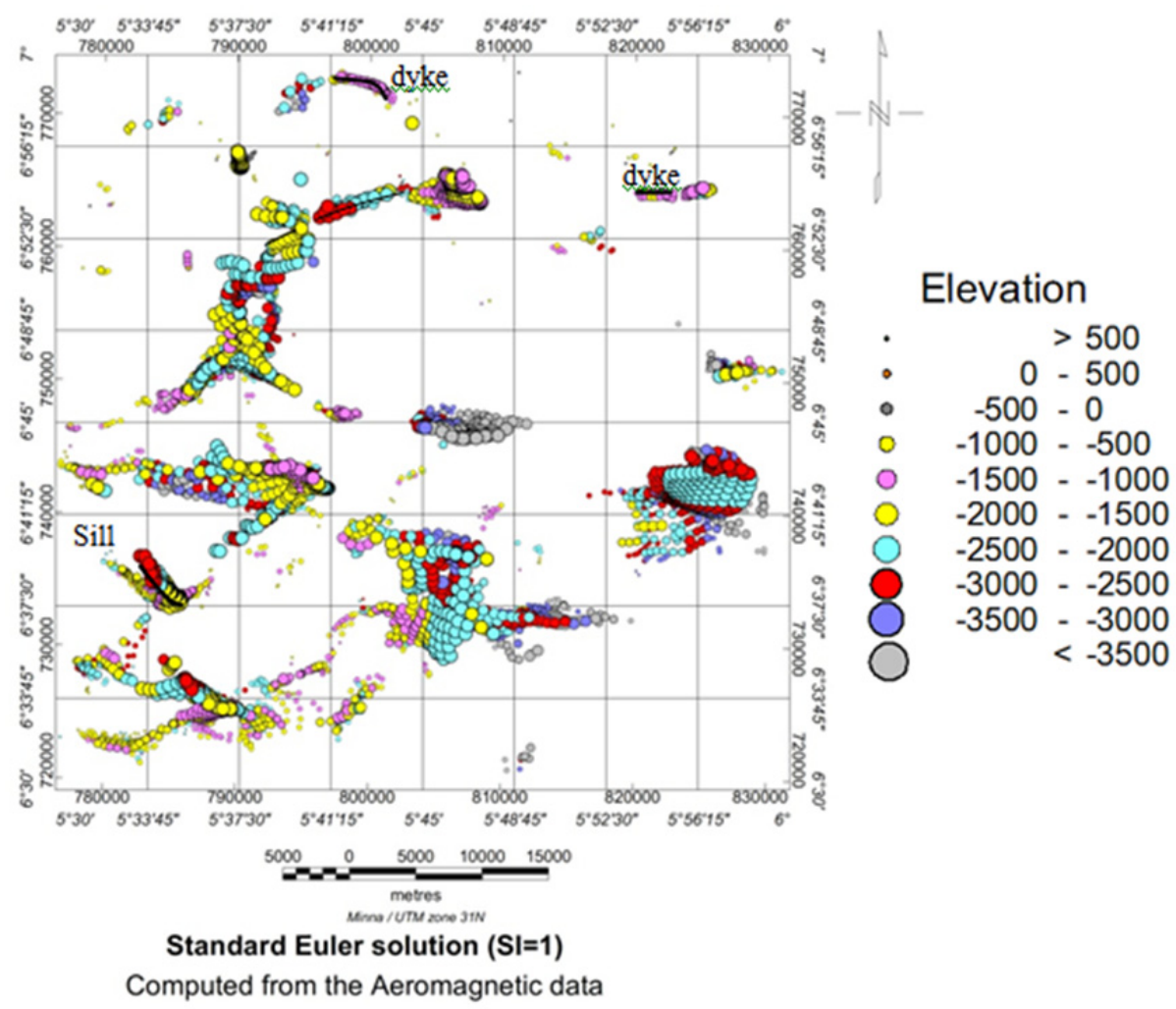

Figure 13. Results of Euler 3D Euler inversion of the aeromagnetic data for the Sill/Dyke model (structural index $=1.0)$

Table 3. Statistical Summary of Standard Euler Depth Inversion of the Aeromagnetic Data for Various Source Geometry

\begin{tabular}{|c|c|c|c|c|c|c|c|c|}
\hline \multirow[t]{2}{*}{ SI } & \multirow{2}{*}{$\begin{array}{l}\text { Number of } \\
\text { reliable } \\
\text { solution }\end{array}$} & \multirow{2}{*}{$\begin{array}{l}\text { Min } \\
\text { depth } \\
(\mathrm{m})\end{array}$} & \multirow{2}{*}{$\begin{array}{l}\text { Max } \\
\text { depth } \\
(\mathrm{m})\end{array}$} & \multirow[t]{2}{*}{$\begin{array}{l}\text { Range } \\
(\mathrm{m})\end{array}$} & \multirow{2}{*}{$\begin{array}{l}\text { Average } \\
\text { depth, } \bar{x} \\
\text { (m) }\end{array}$} & \multirow[t]{2}{*}{$\begin{array}{l}\text { Std; } \\
(\mathrm{m})\end{array}$} & \multicolumn{2}{|c|}{$\begin{array}{l}68 \% \text { confidence limit' } \\
\text { thresh hold; } \quad(\mathrm{m})\end{array}$} \\
\hline & & & & & & & $\begin{array}{c}\text { Lower limit } \\
(\bar{x} \text {-Std })\end{array}$ & $\begin{array}{l}\text { Upper limit } \\
(\bar{x}+\text { Std })\end{array}$ \\
\hline 0.0 & 744 & 567.55 & 5496.61 & 4929.06 & 1700.708 & 883.7668 & 816.9412 & 2584.475 \\
\hline 0.5 & 1112 & 350.62 & 5352.14 & 5001.52 & 2530.305 & 762.4853 & 1767.82 & 3292.79 \\
\hline 1.0 & 1397 & 196.63 & 5412.85 & 5216.22 & 3047.513 & 817.6337 & 2229.879 & 3865.147 \\
\hline 2.0 & 1006 & 1759.93 & 5478.9 & 3718.97 & 3841.198 & 850.668 & 2990.53 & 4691.866 \\
\hline 3.0 & 407 & 2270.8 & 5525.27 & 3254.47 & 4257.046 & 829.0996 & 3427.946 & 5086.146 \\
\hline
\end{tabular}

Table 4. Statistical Summary of Located Euler Depth Inversion of the Aeromagnetic Data for Various Source Geometry

\begin{tabular}{|c|c|c|c|c|c|c|c|c|}
\hline \multirow[t]{2}{*}{ SI } & \multirow{2}{*}{$\begin{array}{c}\text { Number of } \\
\text { reliable } \\
\text { solution }\end{array}$} & \multirow{2}{*}{$\begin{array}{l}\text { Min } \\
\text { depth } \\
(\mathrm{m})\end{array}$} & \multirow{2}{*}{$\begin{array}{c}\text { Max } \\
\text { depth } \\
(\mathrm{m})\end{array}$} & \multirow[t]{2}{*}{$\begin{array}{l}\text { Range } \\
\text { (m) }\end{array}$} & \multirow{2}{*}{$\begin{array}{l}\text { Average } \\
\text { depth, } \bar{x} \\
\text { (m) }\end{array}$} & \multirow[t]{2}{*}{ Std (m) } & \multicolumn{2}{|c|}{$\begin{array}{l}\text { 68\% confidence limit thresh } \\
\text { hold }\end{array}$} \\
\hline & & & & & & & $\begin{array}{c}\text { Lower limit } \\
(\bar{x} \text {-Std })\end{array}$ & $\begin{array}{l}\text { Upper limit } \\
(\bar{x}+\text { Std })\end{array}$ \\
\hline 0.0 & 810 & 286.03 & 5002.69 & 4716.66 & 1393.163 & 763 & 629.3587 & 2156.967 \\
\hline 0.5 & 1827 & 279.13 & 4982.85 & 4703.72 & 1824.441 & 756.4578 & 1067.983 & 2580.899 \\
\hline 1.0 & 1930 & 439.96 & 5490.65 & 5050.69 & 2292.624 & 893.1063 & 1399.518 & 3185.73 \\
\hline 2.0 & 1639 & 695.67 & 5439.3 & 4743.63 & 3007.979 & 938.653 & 2069.326 & 3946.632 \\
\hline 3.0 & 1104 & 987.65 & 5483.48 & 4495.83 & 3498.829 & 910.5341 & 2588.295 & 4409.363 \\
\hline
\end{tabular}




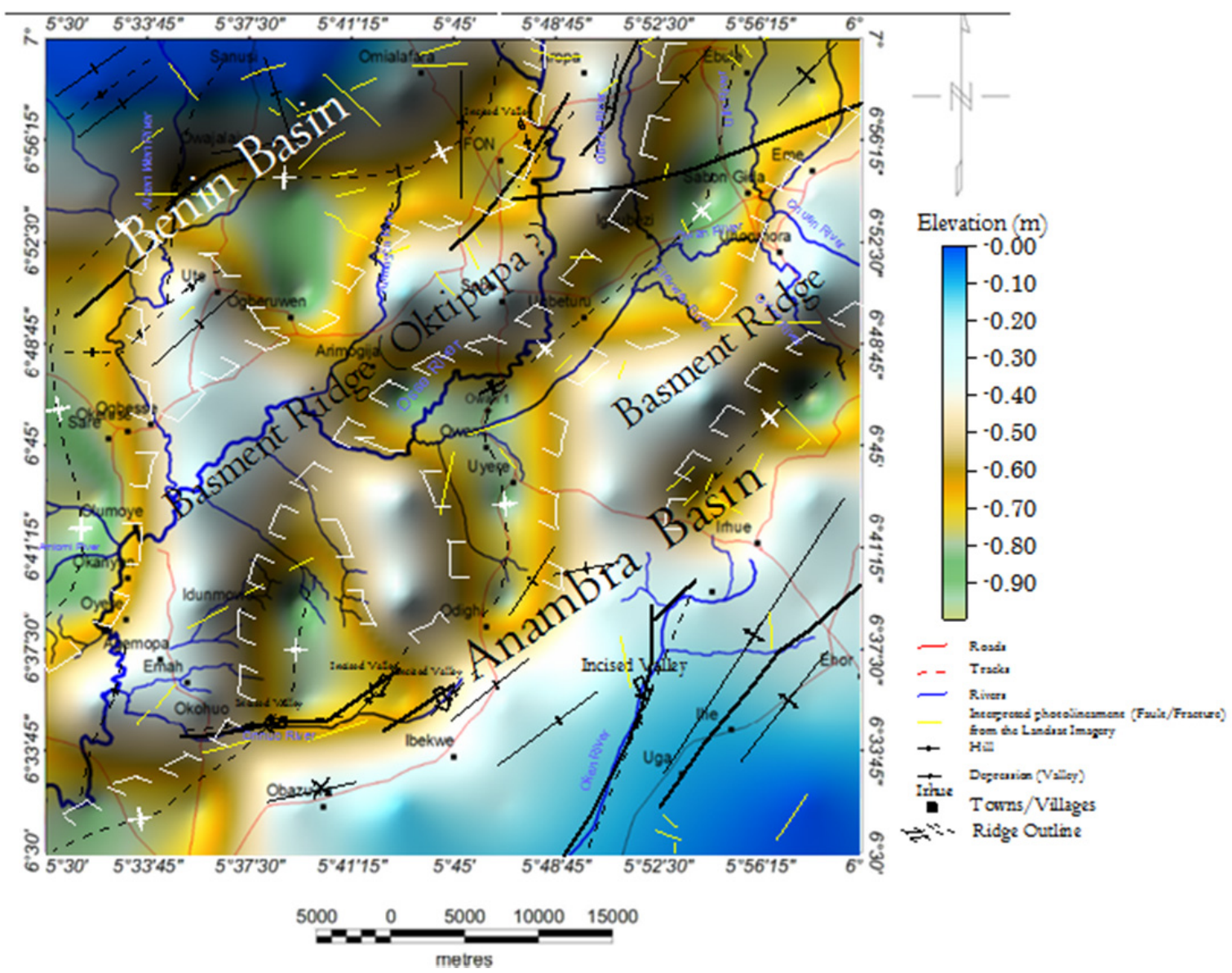

Figure 14. Overlay of Lineament Features from DEM and Landsat Image over Bedrock Relief Map

\section{Discussion}

Figure 14 shows the bedrock relief map of the study area derived from the information on depth-to-source from the magnetic data interpretation from the Euler solution of the magnetic total field intensity data. Superimposed on this map are the interpreted lineaments from the remotely sensed Landsat data and digital elevation model of the topography of the area. Identified on this map are series of SE-NW, E-W and S-N trending anomaly peaks orientation, which conform to the inferred general geologic trend in the extracted lineaments map from the Landsat imagery.

In Figure 14 the structural features or (tectonic elements) identified are:

1. major NE trending Faults;

2. bedrock depressions (or grabens) indicated by surface elevation deeper than $0.75 \mathrm{~km}$, which coincides with magnetic low in SW-NE direction on the magnetic map close to the central part of the study area;

3. a SW-NE trending bedrock uplifts (bedrock ridges or horsts) indicated by continuity of surface elevation between $0.25 \mathrm{~km}$ and $0.50 \mathrm{~km}$; and

4. basement uplift (horst) shown as surface elevation shallower than $0.15 \mathrm{~km}$ in the north, northwestern and southeastern parts of the study area

The interpreted basement ridge in the central part of the study has been recognised to form alignment with the deep sea transform/fracture zone system recognised as Chain transform/fracture zone (Figures 15). The walls of the inland extension of the underlying ridges coincide with the inferred onshore projection of the two major extensions of Chain transform faults. These fracture zones appear to play major roles in the deformation and rifting of the sheared south-western Nigeria basin margins.

The transform fracture zone is responsible for the strike-slip deformations resulting into the graben-horst patterns 
which influence deposition of sediments from major rivers draining the area from the north to the southern basin margins. Series of the normal/strike-slip faults form major boundaries between the Dahomey basin to the left from the adjacent Benin basin, and the boundary between Banin and Anambra Basin.

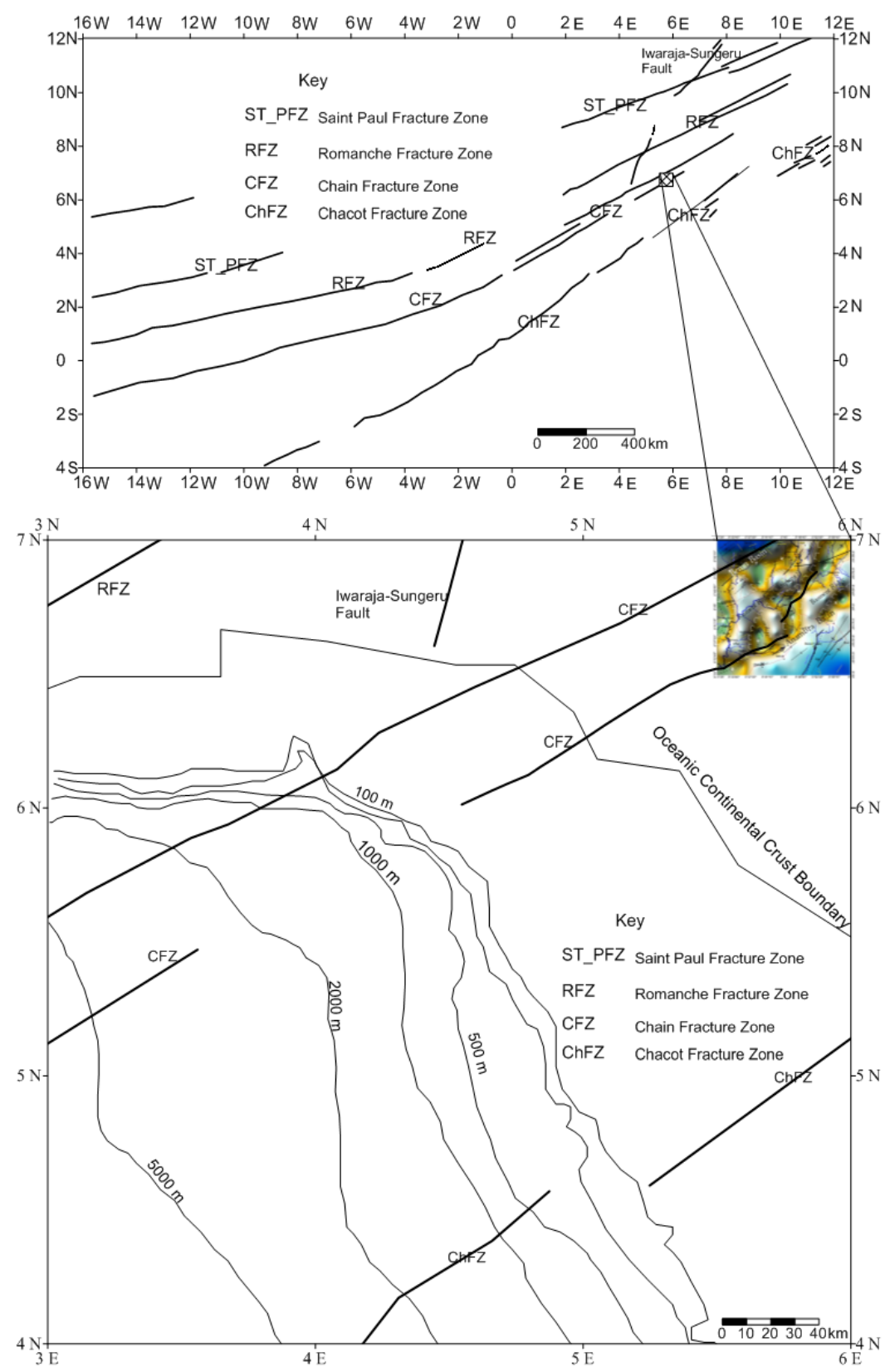

Figure 15. (a) Sketch map showing major deep ocean fracture zones (redrawn from Selemo and Akaolisa, 2010; Samaila and Likkason, 2013), and (b) Inland extension of the Chain transform/fracture zone into the continental margins of the south-western Nigeria

\section{Conclusion}

The information obtained via the photo-lineament extraction in conjunction with the results of geophysical investigation assisted in the update of geographic information on existing geological map of the study area. This study has shown the basement relief of the area investigated shows intensive post-rift deformation resulting in abrupt vertical changes in basement relief and consequently variation in the thickness of overlying sediments. The interpreted basement fractures/faults penetrates into the overlying Cretaceous and Tertiary sediments.

The modified geologic map shows an improvement on the location of the structural and lithological contacts in comparison to the original geologic map. The ridge mapped in central part of the study area coincides with the Okitipupa, whose edge is marked a major SW-NE trending fault that forms inland extension of the subsurface 
continuation of the SW/NE trending Chain fracture zone of the West African shield. This major SW-NE trending fault has been observed to be the boundary between the Benin Basin to the west and Anambra basin to the east of the study area.

The main SW-NE trending fracture/fault zones are traced to the inland extension of deep ocean Chain and Charcot fault zones. Although, the transition areas of Nigeria coastal areas have not experience any major seismic events, there have been series of inland tremors within the south-western parts of Nigeria.

It is observed that the inland extensions of the Charcot and Chain fracture zones into the sedimentary-basement embayment of Nigeria might trigger seismic activities. This has corroborates the fact that the Nigeria section of the Gulf of Guinea continental margin is gradually becoming active as recorded within some inland areas of the county. It is therefore just a matter of time that the fracture zones of the Atlantic traced to the major SSW-NNE shear or fracture zones of the south-western Nigeria Embayment as displayed by Migmatite gneiss complex which form the basement rock in the study area, may induce seismic events of notable size and magnitude.

\section{References}

Ako, B. D., Ojo, S. B., Okereke, C. S., Fieberge, F. C., Ajayi, T. R., Adepelumi, A. A., Afolayan, J. F., Afolabi, O., \& Ogunnusi, H. O. (2004). Some observation from gravity/magnetic data interpretation of the Niger Delta. Nigerian Association of Petroleum Explorationists, 17(1), pp 1-21.

Ako, B. D. Adegoke, O. S., \& Peter, S. W. (1980). Stratigraphy of the Ososhun formation in southwestern Nigeria. Journal of Mining Geology, 17(1), 97-106.

Mohammed, A., Palanivel, K., \& Kumanan, C. J. (2010). Significance of Surface Lineaments for Gas and Oil Exploration in Part of Sabatayn Basin-Yemen. Journal of Geography and Geology, 2(1), 119-128. http://dx.doi.org/10.5539/jgg.v2n1p119

Bhattarcharyya, B. K. (1966). Continuous spectrum of the total magnetic field anomaly due to a rectangular prismatic body. Geophysics, 31, 97-121. http://dx.doi.org/10.1190/1.1439767

Billman, H. G. (1992). Offshore stratigraphy and paleontology of Dahomey (Benin) embayment, West Africa. Nigerian Association of Petroleum Explorationists Bulletin, 7(2), 121-130.

Blakely, R. J. (1996). Potential theory in Gravity and Magnetic Applications, (Reprint). Cambridge University Press. U.K., p. 441.

Bournas, N., \& Baker, H. A. (2001). Interpretation of magnetic anomalies using the horizontal gradient and analytical signal. Annali di Geofisica, 44(3), 505 - 526.

Cordell, L., \& McCafferty, A. E. (1989). A terracing operator for physical property mapping with potential field data. Geophysics, 54, 621-634. http://dx.doi.org/10.1190/1.1442689

Dewangan, P., Ramprasad, T., Ramana, M. V., Desa, M., \& Shailaja, B. (2007). Automatic interpretation of magnetic data using Euler deconvolution with nonlinear background. Pure and Applied Geophysics, 164, 2359-2372. http://dx.doi.org/10.1007/s00024-007-0264-x

Ekweozor, C. M. (1991). Geochemistry of oil and sands of southwestern Nigeria. Nigerian Association of petroleum Explorationists Bulletin, 6(2), 77-88.

Ekwueme, B. N. (2003). The Precambrian geology and evolution of the southeastern Nigeria Basement Complex. University of Calabar Press, Calabar, Nigeria. P. 135.

Githiri, J. G., Patel, J. P., Barongo, J. O., \& Karanja, P. K. (2012). Spectral analysis of ground magnetic data In Magadi area, southern Kenya Rift. Tanzanian Journal of Science, 38(1), 1-14.

Hassan, H. H., \& Peirce, J. W. (2007). Mapping geological features in HRM data using 2D steerable filters and its comparison to $2 \mathrm{D}$ wavelet transform, $77^{\text {th }}$ Annual SEG Meeting in San Antonio. SEG Technical Program Expanded Abstracts, pp. 795-799.

Mah, A., Taylor, G. R., Lennox, P., \& Balia, L. (1995). Lineament Analysis of Landsat Thematic Mapper Images, Northern Territory, Australia. Photogrammetric Engineering and Remote Sensing, 61(6), 761-773.

Marson, I., \& Klingele, E. E. (1993). Advantages of using the vertical gradient of gravity for 3-D interpretation: Geophysics, 58, 1588-1595. http://dx.doi.org/10.1190/1.1443374

Nabighian, M. N., (1984). Toward a three-dimensional automatic interpretation of potential field data via generalised Hilbert transforms: Fundamental relations. Geophysics, 49, 780-786. http://dx.doi.org/10.1190/1.1441706 
Nama, E. E. (2004). Lineament Detection on Mount Cameroon During the 1999 Volcanic eruptions Using Landsat ETM. International Journal of Remote Sensing, 25(3), 501-510. http://dx.doi.org/10.1080/0143116031000102557

Nur, M. A., Onuoha, K. M., \& Ofogbue, C. O. (1994). Spectral analysis of aeromagnetic data over the middle Benue trough, Nigeria Journal of Mining and Geology, 32(2), 211-217.

Ogunmola, J. K , Ayolabi, E.A, \& Olobaniyi, S. B. (2014). Lineament extraction from Spot 5 and Nigeria Sat-X imagery of the Upper Benue Trough, Nigeria. International Archives of the Photogrammetry, Remote Sensing and Spatial Information Sciences, Volume XL-1, ISPRS Technical Commission I Symposium, 17 - 20 November 2014, Denver, Colorado, USA. pp. 323-330.

Olayanju, (2010). Geophysical Mapping of Ifon Basement- Sedimentary Area, South-western Nigeria, Unpublished PhD Thesis, Department of Applied Geophysics, Federal University of Technology, Akure, Nigeria, p. 348.

Olayinka, A. (1976). Review of the stratigraphy, sesdimentation and structure of the Niger Delta. In: Geology of Nigeria, Kogbe (Edition). Elizabethan Publishing Co., Lagos, Nigeria. pp. 259-272.

Onuoha, K. M. (1999). Structural features of Nigeria's coastal margin: an assessment based on age data from $\begin{array}{lllll}\text { wells. Journal of African Earth } & \text { Sciences, } & \text { 29(3), } & \text { 485-499. }\end{array}$ http://dx.doi.org/10.1016/S0899-5362(99)00111-6

Onyedim, G. C., Ariyibi, E. A., Awoyemi, M. O., Arubayi, J. B., \& Afolabi, O. M. (2006b). Source parameter imaging from aeromagnetic data of the basement rocks in part of the Middle Benue Through, Nigeria. Journal of Mining and Geology, 42(2), 165-173.

Onyedim, G. C., Awoyemi, M. O., Ariyibi, E. A., \& Arubayi, J. B. (2006a). Aeromagnetic imaging of basement morphology in part of the Middle Benue Through, Nigeria. Journal of Mining and Geology, 42(2), 157-163.

Oruc, B., \& Selim, H. H. (2011). Interpretation of magnetic data in the Sinop area of Mid Black Sea, Turkey, using tilt derivative, Euler deconvolution, and discrete wavelet transform. Journal of Applied Geophysics, 74, 194-204. http://dx.doi.org/10.1016/j.jappgeo.2011.05.007

Peterson, R. M. (1976). Methods for interpretation of geologic structures from Landsat imagery. Geophysics, 41, 369-370.

Phillips, J. D. (1997). Potential-Field Geophysical Software for the PC, version 2.2: U.S. Geological Survey Open-File Report 97- 725.

Pilkington, M., Todoeshuck, J. P., \& Gregotski, M. E., (1994). Using fractal crustal magnetization models in $\begin{array}{llll}\text { magnetic interpretation: Geophysics } & \text { Prospecting, }\end{array}$ http://dx.doi.org/10.1111/j.1365-2478.1994.tb00235.x

Reid, A. B., Allsop, J. M., Granser, H., Millett, A. J., \& Somerton, I. W. (1990). Magnetic interpretation in three dimensions using Euler deconvolution: Geophysics, 55, 80-91. http://dx.doi.org/10.1190/1.1442774

Roest, W. R., Verhoef, J., \& Pilkington, M. (1992). Magnetic interpretation using the 3-D analytic signal. Geophysics, 57, 116-125. http://dx.doi.org/10.1190/1.1443174

Rubin, C. S. (1979). Remote sensing applied to mineral exploration in Southern St. Lawrence country New York. In: Evidence of tectonic control of mineralization in Nigeria from lineament density analysis. Int. Jour. Remote sensing, 8(10), 1445.

Sabins, F. F. (1978). Remote Sensing: Principles and interpretation. San Francisco, W.H. Freeman and Co., 321.

Samaila, N. K., \& Likkason, O. K. (2013). Role of Equatorial Fracture Zones on Fluid Migration across the South Atlantic Margins. Journal of Earth Science Climate Change, 12: 004.

Selemo, A. O. I., \& Akaolisa, C. Z. (2010). Tectonic features interpreted from aeromagnetic maps of Okigwe Oguta axis, South of Benue Trough, Nigeria. International Journal of the Physical Sciences, 5(16), 2450-2457.

Spector, A., \& Grant, F. S. (1970). Statistical models for interpreting aeromagnetic data. Geophysics, 35(2), 293-302. http://dx.doi.org/10.1190/1.1440092

Tanaka, A., Okubo, Y., \& Matsubayashi, O. (1999). Curie point depth based on spectrum analysis of the magnetic anomaly data in East and Southeast Asia. Tectonophysics, 306, 461-470. 
http://dx.doi.org/10.1016/S0040-1951(99)00072-4

Thompson, D. T. (1982). EULDPH: A new technique for making computer-assisted depth estimates from magnetic data. Geophysic, 47, 31 - 37. http://dx.doi.org/10.1190/1.1441278

Umego, M. N., Ojo, S. B., \& Ajakaiye, D. E., (1995). A magnetic depth to basement analysis in the Sokoto basin, Northwestern Nigeria. Journal of Mining and Geology, 63(6), 1965-1970.

\section{Copyrights}

Copyright for this article is retained by the author(s), with first publication rights granted to the journal.

This is an open-access article distributed under the terms and conditions of the Creative Commons Attribution license (http://creativecommons.org/licenses/by/3.0/). 